\title{
Selected aspects of the design and diagnostics of solid oxide fuel cells
}

\author{
Bartłomiej Lis ${ }^{1, a}$ \\ ${ }^{1}$ Faculty of Energy and Fuels, AGH University of Science and Technology in Cracow, Av. A. Mickiewicza 30, Poland
}

\begin{abstract}
An increased growth in demand for energy accompanied by efforts to limit its negative impact on the environment is forcing society to seek new, more efficient energy sources. Fuel cells are one of the most promising solutions among the widely developed new generation of electrical generators. Fuel cells directly convert chemical fuel into electricity. Water and waste heat are by-products of fuel cell operation. Solid oxide fuel cells (SOFCs) have proven to be one of the most interesting solutions among the five types of technologically advanced fuel cells, for their ability to operate at temperatures above $800^{\circ} \mathrm{C}$. Furthermore, SOFCs are characterized by other advantages in comparison to PEMFCs, including: (1) no need to use expensive catalysts (e.g. platinum, the price of which is high, and its resources limited), (2) the possibility of direct, internal conversion of hydrocarbon fuels, (3) lower sensitivity to contaminants (in particular, hydrogen fuel containing CO, which is useful for SOFCs instead of the platinum catalyst poisoners), and (4) the possibility of using waste heat in a gas turbine, or for heating or other industrial purposes. The paper discusses selected issues regarding the construction and characteristics of planar solid oxide fuel cells. Selected results of the following electrochemical investigations: $\mathrm{Ba}_{0,9} \mathrm{Ca}_{0,1} \mathrm{Ce}_{0.9} \mathrm{Y}_{0.1} \mathrm{O}_{3}$-based proton electrolyte as possible components of SOFCs operating at intermediate temperature range $\left(500-700^{\circ} \mathrm{C}\right)$.
\end{abstract}

\section{Introduction}

A fuel cell (FC) is a type of a galvanic cell, along with primary cells, electrochemical accumulator batteries, and flow-through accumulators. As in any galvanic cells, what occurs in an FC is a direct (single-stage) conversion of chemical fuel energy into electricity (and waste heat). A characteristic feature of FCs is that the electroactive substances, i.e. the oxidiser and the fuel, are delivered to them from outside, and the reaction product is removed from the fuel cell [1-7].

Currently, the most rapid technological development can be observed for proton exchange membrane fuel cells (PEMFCs) and solid oxide fuel cells (SOFCs). Small units with fuel cells (with power ranging from several up to a dozen watts, mainly PEMFCs) have already appeared on the commercial market; they can be used, for example, to power portable electronics or mobile phones. Slightly larger stacks of fuel cells (approximately 250-1000 W) can serve as power sources for electric motors for unmanned aerial vehicles (drones). Even larger fuel cells (1-200 kW) are being built for application in cars and small planes. Stationary units, with power in megawatts [8-13], have been commercialised for phosphoric acid fuel cells (PAFCs) and molten carbonate fuel cells (MCFCs), whereas the development of PEMFCs and SOFCs remains consistently at the level of advanced prototype units.

Among five types of technologically advanced fuel cells special attention should be given to solid oxide fuel

\footnotetext{
a Corresponding author: blis@agh.edu.pl
}

cells (SOFCs). Solid oxide fuel cells which currently utilise $\mathrm{ZrO}_{2}-\mathrm{Y}_{2} \mathrm{O}_{3}$ as solid electrolytes operate at temperatures of $850-1000^{\circ} \mathrm{C}$ and require the use of components (i.e. electrodes and interconnectors) made from materials characterised by high thermal and chemical stability as well as high corrosion resistance in an oxidation-reduction environment. This vastly increases the cost of producing fuel cells, due to the high cost of suitable materials, and limits their use [14].

The reduction of operation temperature to $550-700^{\circ} \mathrm{C}$ seems to be most important strategic goal of SOFC technology. There are two main approaches to solve this problem. The application of some oxygen ionic conductors as well as proton conducting ceramics, which exhibited higher ionic conductivity than 8YSZ at intermediate temperature range seem to be most often considered solution. Ceria-based solid electrolytes still seem to be the most attractive oxide conducting ceramic membranes at intermediate temperature ranges $(600$ $\left.800^{\circ} \mathrm{C}\right)[15-17]$. The utilization of ceramic proton conducting membrane instead to oxygen ionic conductor as an electrolyte in SOFCs can lead to simplification of the SOFC stacks construction. In SOFCs with a ceramic proton conducting membrane, the water evolves on the cathode, avoiding the fuel dilatation on the anode side, as well as reduction of cell voltage.

At present, high protonic conduction is reported for several perovskite-type oxides, such as doped $\mathrm{BaCeO}_{3}$, $\mathrm{SrCeO}_{3}, \mathrm{BaZrO}_{3}$, and $\mathrm{SrZrO}_{3}$. Proton conduction can be 
thermally activated at comparatively low temperatures $\left(400-700^{\circ} \mathrm{C}\right)$ due to the low activation energy $(0.3-0.6$ $\mathrm{eV})$ required by this process $[18,19]$.

Currently, research and development for SOFCs are conducted in order to improve the efficiency of conversion of chemical energy of fuels into electrical energy in these devices. These efforts are also aimed at improving the reliability of fuel cells, prolonging their life, and reducing the costs of single cells and their stacks. The results of this work are modifications in the already produced SOFC stack systems, and the construction of a new type of a SOFC [20].

The latter requires confirmation of the effectiveness of its performance. Due to the cost of SOFC components, as well as the cost production of SOFCs, electrochemical tests are usually performed for SOFCs of small sizes. For this reason, the most often applied systems are button solid oxide fuel cells. The basic element of this measurement station is a button solid oxide fuel cell with electrodes with a maximum geometric surface area of $2 \mathrm{~cm}^{2}$. Standardising procedures can be easily introduced for this kind of SOFC construction, as they will take into account, among other factors, the size of the active surface of the electrode material, the impact of the ohmic polarisation, and the area of the surface changes in the electrode material, or the electrolyte after long-term testing for all single SOFC performances.

The aim of this study is to determine the possibility of designing a SOFC operating in the temperature range of $600-800^{\circ} \mathrm{C}$ using a $\mathrm{BaCeO}_{3}$-based ceramic proton conductor.

\section{Experimental}

A solid-state proton-conducting electrolyte ( $\mathrm{Ba}_{0.9} \mathrm{Ca}_{0.1} \mathrm{Ce}_{0.9} \mathrm{Y}_{0.1} \mathrm{O}_{3-\mathrm{d}}, 10 \mathrm{CBCY}$ ) was fabricated via the sol-gel method. Stoichiometric amounts of $\mathrm{BaCO}_{3}$, $\mathrm{CaCO}_{3}$, and $\mathrm{Y}_{2} \mathrm{O}_{3}$ were dissolved in nitric acid and mixed with a $\mathrm{Ce}\left(\mathrm{NO}_{3}\right)_{2}$ solution. In a separate beaker, EDTA was dissolved in an ammonia solution diluted with distilled water. The two solutions were mixed and heated to $80^{\circ} \mathrm{C}$. The ratio of total metal cations to EDTA was maintained at $1: 1.1$. As a result of continuous heating and stirring, excess water was evaporated and a viscous gel was formed. The gel was placed in a furnace and heated to $900^{\circ} \mathrm{C}$. White ash was collected and milled in an agate mortar in the presence of isopropanol. Subsequently, the powder was heated to $1000^{\circ} \mathrm{C}$ for $2 \mathrm{~h}$.

The powder was grounded in an agate mortar and uniaxially pressed in a $28 \mathrm{~mm}$ pressing die under 9 tonnes of force. Then the sample was sintered at $1500^{\circ} \mathrm{C}$ for $2 \mathrm{~h}$. The sintered sample was cut into the shape of a circle with a diameter of $20 \mathrm{~mm}$. Both sides of the samples were grounded and polished. Platinum paste electrodes were screen-printed on both sides of the cylindrical cell. In order to sinter the electrodes with the cell surfaces, the sample was heat-treated in air at $815^{\circ} \mathrm{C}$ for $15 \mathrm{~min}$. The anode and cathode surfaces of the commercial cell were screenprinted with a platinum honeycomb network current collector (Fig.1 a-b). The prepared powder and sintered electrolyte were examined using the X-ray diffraction method.
Solid oxide button fuel cells (proton- and oxideconducting) were tested using an elaborated setup (Fig.1c-d). Single SOFCs cells were placed inside a ceramic socket and pressed with another alumina tube in order to obtain a gastight configuration, gold gaskets were placed on both sides of the cell.

Hydrogen was supplied from a bench-scale PEM electrolyser using a liquid-gas water separator. In the case of the solid oxide button cell, $20 \%$ oxygen in an argon mixture was fed to the cathode. A Solartron electrochemical interface (SI1287) with a frequency response analyser (FRA 1255B) was used for electrochemical measurement. Impedance spectroscopy measurements were also performed to identify the sources of electrochemical losses during SOFC performance.

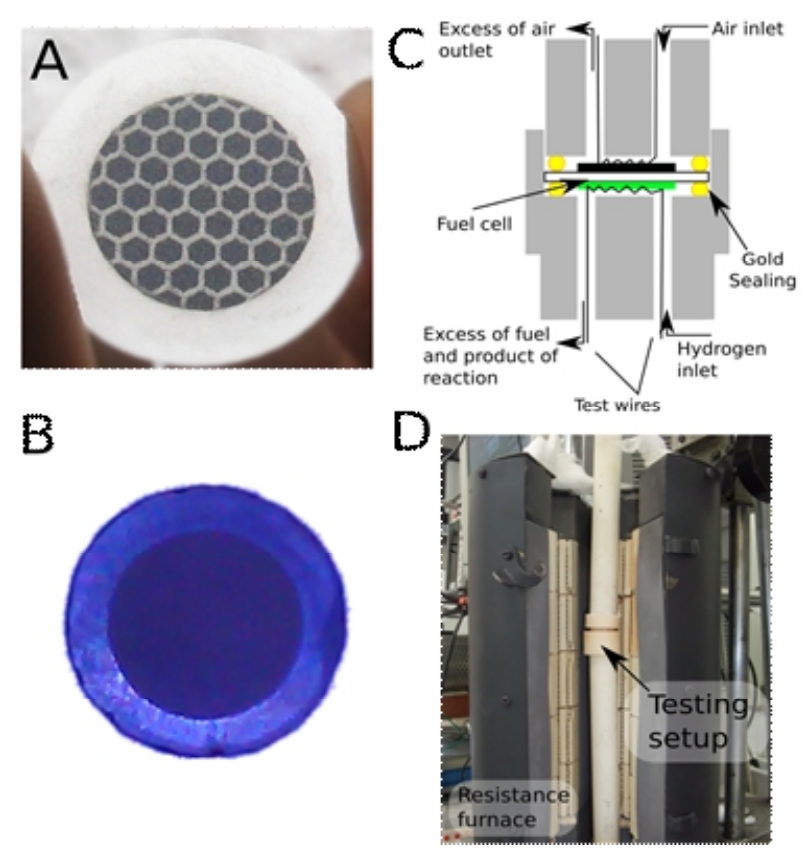

Figure 1. Photographies of tested electrolyte - supported solid oxide fuel cells. A) The cathode side of the solid button oxide fuel cell, B) The 10CBCY electrolyte with printed Pt electrodes. C) The scheme of electrochemical testing setup, D) The electrochemical testing setup inside opened furnace.

\section{Results and discussions}

The details of structural and physicochemical investigations of $\mathrm{Ba}_{1-\mathrm{x}} \mathrm{Ca}_{\mathrm{x}} \mathrm{Ce}_{0.9} \mathrm{Y}_{0.1} \mathrm{O}_{3-\mathrm{d}}$-based solid solutions were presented in the previous paper [21]. Analysis of the electrical conductivity of both series of investigated materials showed that the highest ionic conductivity, in air and wet $5-10 \% \mathrm{H}_{2}$ in $\mathrm{Ar}$, was attained by compositions of $\mathrm{x}=0.02-0.05$ $\left(\mathrm{Ba}_{1-\mathrm{x}} \mathrm{Ca}_{\mathrm{x}}\right)\left(\mathrm{M}_{0.9} \mathrm{Y}_{0.1}\right) \mathrm{O}_{3}, \mathrm{M}=\mathrm{Zr}$, Ce.

Figure 2 presents the XRD diffraction pattern obtained for $\mathrm{BaCe}_{0.9} \mathrm{Y}_{0.1} \mathrm{O}_{3-\mathrm{d}}$ (BCY) as well as $\mathrm{Ba} 0 .{ }_{9} \mathrm{Ca}_{0.1} \mathrm{Ce}_{0.9} \mathrm{Y}_{0.1} \mathrm{O}_{3-\mathrm{d}} \quad(10 \mathrm{CBCY})$ sintered samples. The introduction of $10 \%$ calcium cations in place of barium in the solid solution $\mathrm{Ba}_{0 .} \mathrm{Ca}_{0.1} \mathrm{Ce}_{0.9} \mathrm{Y}_{0.1} \mathrm{O}_{3-\mathrm{d}}$ left the perovskite structure unchanged. Button solid oxide fuel cells incorporating electrode material with an active surface area of about $1.3-2 \mathrm{~cm}^{2}$ are very often used in solid oxide fuel cell technology as standardised 
ceramic elements for preliminary electrochemical tests. Ceramic shaped parts in these sizes are very often offered by well-known fuel cell manufacturers as a reference for tests of single SOFCs $[22,23]$.

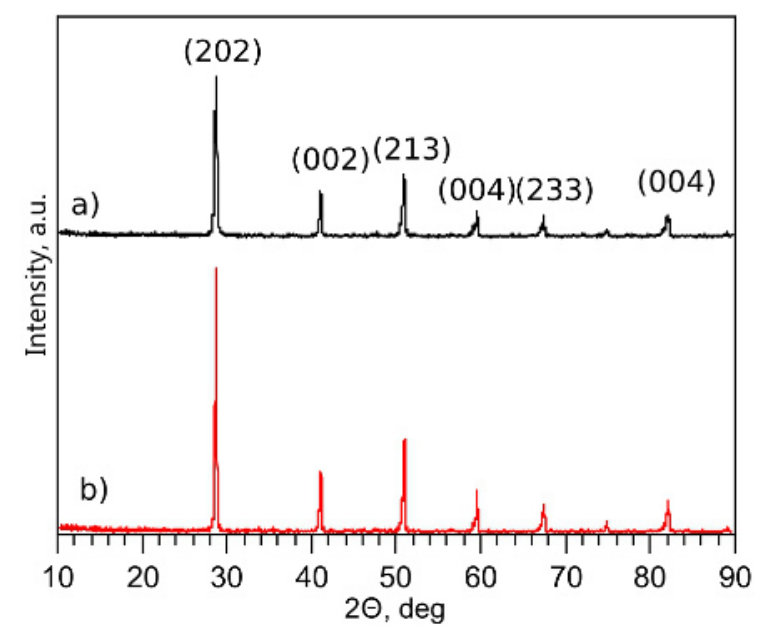

Figure 2. The X-ray diffraction pattern recorded for BCY (a) and $10 \mathrm{CBCY}$ (b) sintered samples.

In this study efforts were aimed at the manufacture of gastight $\mathrm{Ba} 0.9 \mathrm{Ca}_{0.1} \mathrm{Ce}_{0.9} \mathrm{Y}_{0.1} \mathrm{O}_{3-\mathrm{d}}$ sintered samples with diameters about $2 \mathrm{~cm}$ and the performance tests of hydrogen-oxygen solid oxide fuel cells. Figure $3 a-b$ presents a photo of commercial $8 \% \mathrm{~mol} \mathrm{Y}_{2} \mathrm{O}_{3}$ in $\mathrm{ZrO}_{2}$ 8YSZ ceramic foil (Fuel Cell Material, USA) used as a reference electrolytic material and a newly manufactured ceramic $10 \mathrm{CBCY}$ proton-conducting electrolyte. Based on this comparison, plane-parallel ceramic discs based on 10CBCY were obtained.

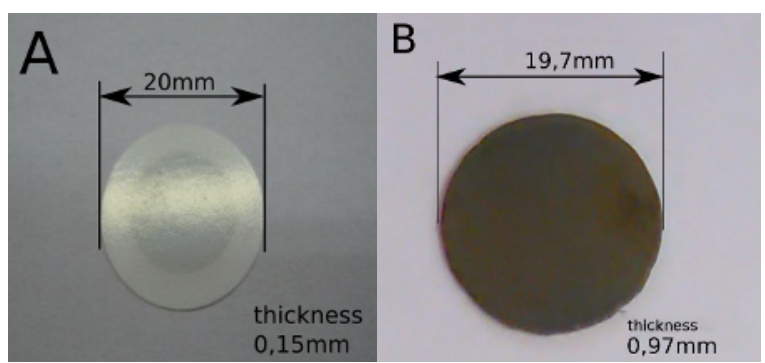

Figure 3. a) Photo of commercial 8YSZ ceramic electrolyte foil (supplier Fuel Cell Material, USA)b) Photo of a newly manufactured ceramic $10 \mathrm{CBCY}$ proton conducting electrolyte

The microscopic investigations performed on $10 \mathrm{CBCY}$, using confocal, atomic force microscopy as well as scanning electron microscopy (Figure $4 \mathrm{a}, \mathrm{b}$ ), showed no open porosity in the sintered sample.

The image of surface of the elaborated cell was compared with surface of commercial electrolyte presented on figure 4 (c,d). No significant differences in roughness was observed.

Electrochemical tests of a single SOFC were performed for reference solid button oxide fuel cells (Fuel Cell Materials, USA). The aim of these investigations was the verification of correct performance and the reproducibility measurements.

The characteristic U-I and P-I curves was presented in Figure 5.
A

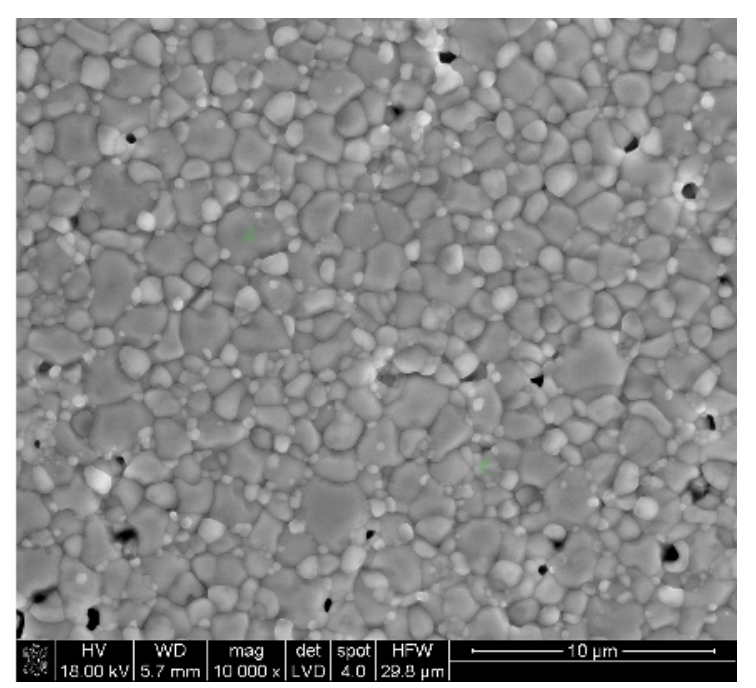

Figure 4a. Scanning electron microscopy image of the microstructure of a $10 \mathrm{CBCY}$ sample sintered at $1500^{\circ} \mathrm{C}$ for $2 \mathrm{~h}$.

\section{B}

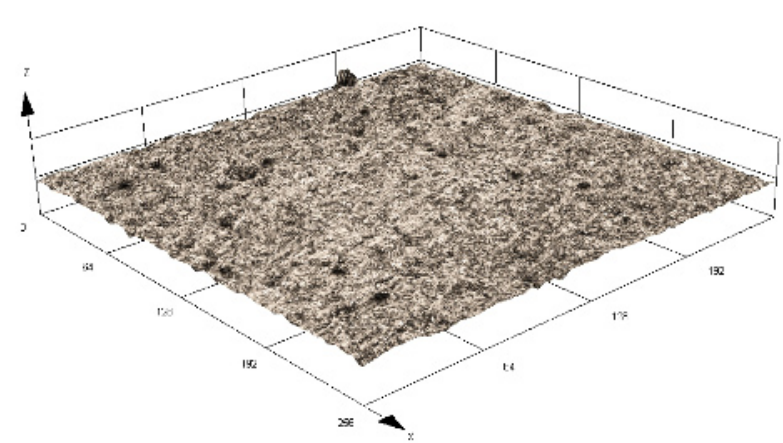

Figure 4b. Image of the surface of a $10 \mathrm{CBCY}$ sample sintered at $1500^{\circ} \mathrm{C}$ for $2 \mathrm{~h}$. The observations were carried out under optical confocal microscopy.

The data obtained for a commercial E-SOFC (Fuel Cell Material) was compared with the parameter declaration provided by the manufacturer [22].

As can be seen, current density (I) and power density (P) increase with rising temperature. The obtained power outputs $P_{\max }$ are very close to data provided by the supplier of the components of this SOFC. Figure 6 presents the family of voltage (U)-current (I) and of power (P)-current (I) curves recorded for an $\mathrm{H}_{2}, \mathrm{Pt}|10 \mathrm{CBCY}| \mathrm{Pt}, \mathrm{O}_{2}$ fuel cell over a range of $550-750^{\circ} \mathrm{C}$. An increase was reported in the current density (I) as well as power density (P) in an SOFC involving a 10CBCY solid electrolyte. These results were compared with data in the literature. Matsumoto et al. [12] investigated an IT-SOFC in which a $\mathrm{BaCe}_{0.9} \mathrm{Y}_{0.1} \mathrm{O}_{3-\mathrm{d}}$ electrolyte with a thickness of $0.5 \mathrm{~mm}$ was tested. In the case of $\mathrm{H}_{2}, \mathrm{Ni}-\mathrm{BCY}|\mathrm{BCY}| \mathrm{LSCF}, \mathrm{O}_{2}$, he obtained a power output of $60 \mathrm{~mW} / \mathrm{cm}^{2}$ at $700^{\circ} \mathrm{C}$. The main difference between the lower power output $\left(15 \mathrm{~mW} / \mathrm{cm}^{2}\right)$ obtained for a SOFC involving $10 \mathrm{CBCY}$ as an electrolyte and the SOFC investigated by Matsumoto can be directly attributed to the difference in the thickness 
of the electrolyte and the different cathode and anode materials applied in the cited paper. The results obtained by the author in this study appear to be valuable for further electrochemical investigations.
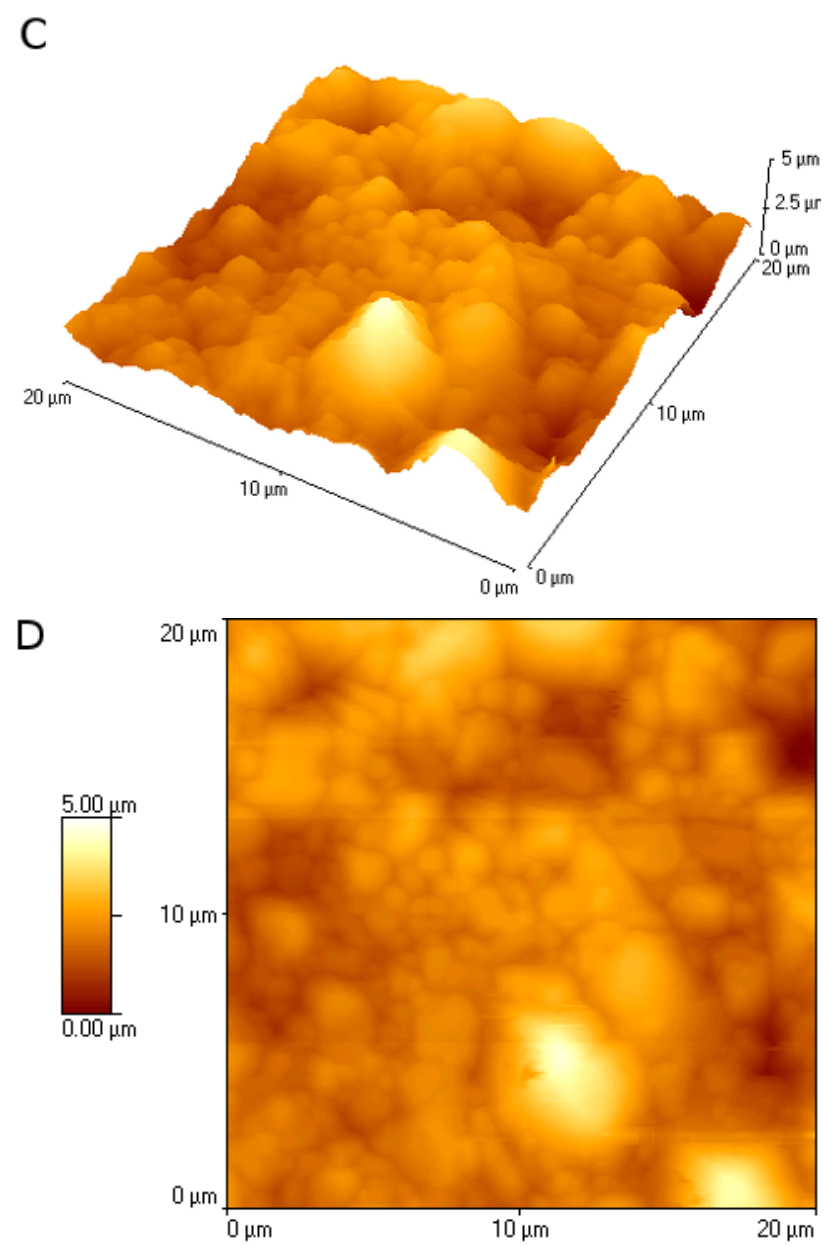

Figure 4.c,d Image of the surface of commercial 8YSZ ceramic electrolyte foil (supplier Fuel Cell Material, USA) obtained by atomic force microscope (AFM).

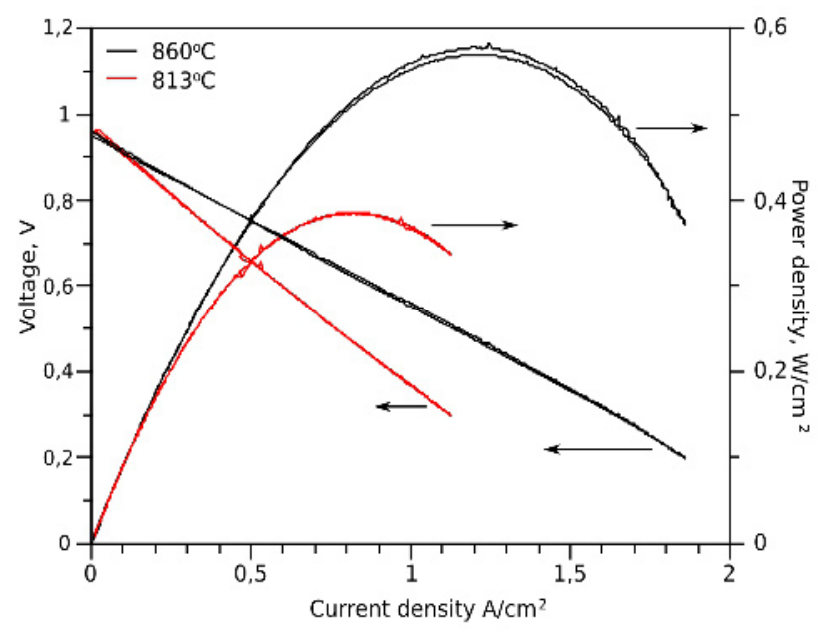

Figure. 5 The U-I curves recorded for an E-SOFC (Fuel Cell Material, SOFCs)

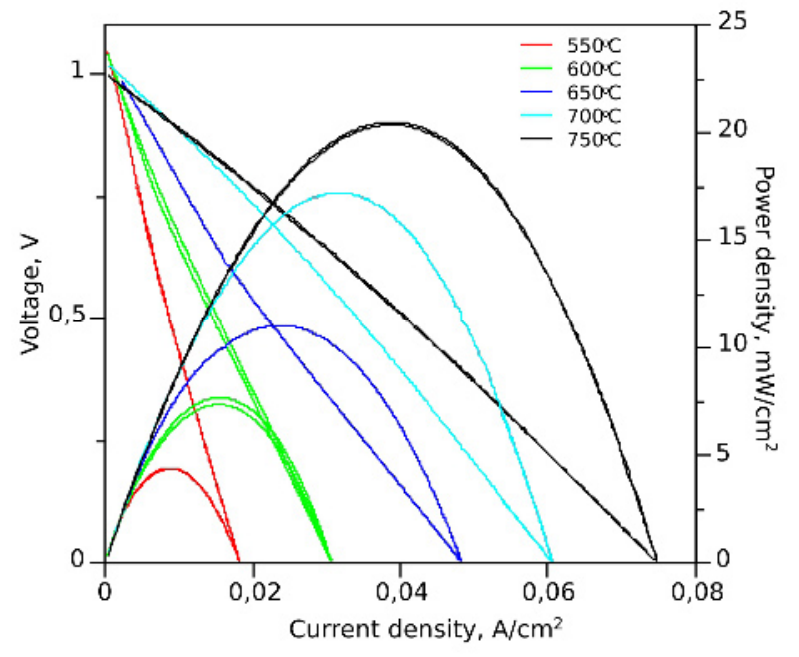

Figure 6. Voltage - Current density and Power density characteristics recorded for an $\mathrm{H}_{2}, \mathrm{Pt}|10 \mathrm{CBCY}| \mathrm{Pt}, \mathrm{O}_{2}$ fuel cell over a temperature range of $550-750^{\circ} \mathrm{C}$

The electrochemical impedance spectroscopy (Figure 7) method was used to determine the impact of ohmic resistance $\left(R_{s}\right)$ and $\left(R_{p}\right)$ on the performance of the tested SOFC with a 10CBCY electrolyte. The data are collected in Table 1.

Table 1. The values of ohmic resistance (Rs) and polarisation resistance (Rp) determined for a $\mathrm{H}_{2}, \mathrm{Pt}|10 \mathrm{CBCY}| \mathrm{Pt}, \mathrm{O}_{2}$ fuel cell within a temperature range of $600-650^{\circ} \mathrm{C}$

\begin{tabular}{|c|c|c|}
\hline Temperature $\left[{ }^{\circ} \mathrm{C}\right]$ & $\mathrm{R}_{\mathrm{s}}[\Omega]$ & $\mathrm{R}_{\mathrm{p}}[\Omega]$ \\
\hline 600 & 14.9 & 18.1 \\
\hline 650 & 11.1 & 5.9 \\
\hline
\end{tabular}

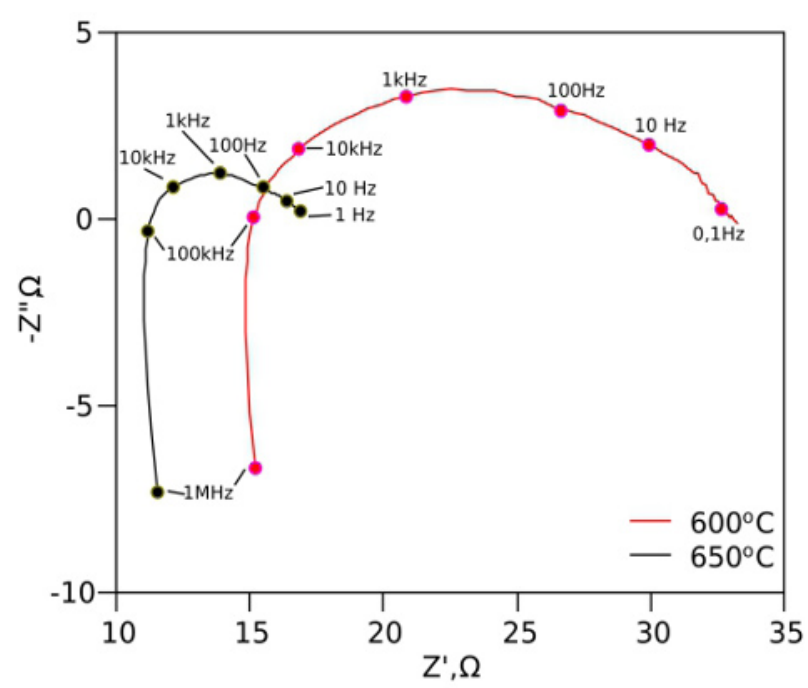

Figure 7. Electrochemical impedance spectra recorded for a $\mathrm{H}_{2}, \mathrm{Pt}|10 \mathrm{CBCY}| \mathrm{Pt}, \mathrm{O}_{2}$ fuel cell at various temperatures.

Based on data presented in Table 1, it was found that the values of Rs and Rp decrease with increasing temperatures of SOFC operation. This phenomenon is typical for SOFCs which are constructed correctly. The values of both $\mathrm{R}_{\mathrm{s}}$ and $\mathrm{R}_{\mathrm{p}}$ obtained by EIS method, 
are in good agreement with data obtained from U-I measurements.

Electrochemical impedance spectroscopy measurements were also performed in an oxygen-rich and a hydrogen-rich gas atmosphere. The recorded impedance plots in the $Z^{\prime \prime}-Z$ coordination are presented in Figure $8 \mathrm{a}$ b. The values of $R_{p}$ and $R_{s}$ are collected in Table 2 .
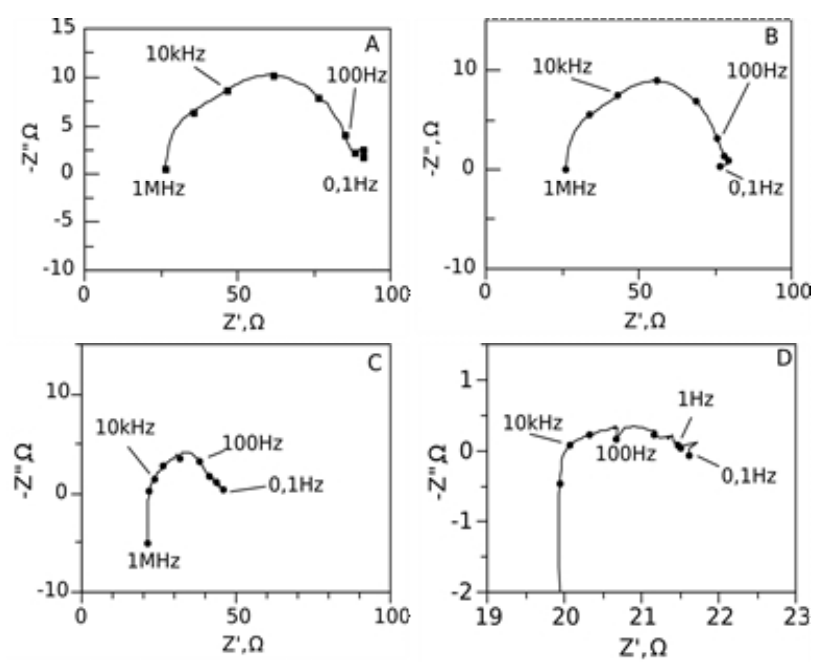

Figure 8. Electrochemical impedance spectroscopy of a symmetrical $\mathrm{Pt}|10 \mathrm{CBCY}| \mathrm{Pt}$ cell in various gas atmospheres at $550^{\circ} \mathrm{C}$ : a) air, b) humidified oxygen $(20 \%)$ with argon, c) fuel cell conditions; d) humidified hydrogen.

Table 2. Values of Rs and $\mathrm{Rp}$ recorded for $\mathrm{Pt}|\mathrm{BC} 10 \mathrm{CY}| \mathrm{Pt}$ in different gas atmospheres

\begin{tabular}{|c|c|c|}
\hline Gas atmospheres & $\mathrm{R}_{s}[\Omega]$ & $\mathrm{R}_{\mathrm{p}}[\Omega]$ \\
\hline $\begin{array}{c}\mathrm{H}_{2} \\
\text { (humidified) }\end{array}$ & 19.9 & 1.7 \\
\hline $\begin{array}{c}\text { Fuel cell condition, } \mathrm{H}_{2} \\
\text { (humidified) }+20 \% \mathrm{O}_{2} \\
\text { in Ar (humidified) }\end{array}$ & 2.3 & 24.8 \\
\hline $\begin{array}{c}20 \% \mathrm{O}_{2} \text { in } \mathrm{Ar} \\
\text { (humidified) }\end{array}$ & 26.0 & 26.0 \\
\hline Air & 52.0 & 65.0 \\
\hline
\end{tabular}

Analysis of data collected in Table 2 indicated that values of $R_{s}$ and $R_{p}$ decrease with increasing $\mathrm{H}_{2}$ content in gas atmospheres. The highest values of ohmic resistance Rs and polarisation resistance $\mathrm{Rp}$ were found in an oxygen-rich atmosphere. In a highly rich oxygen gas atmosphere, $\quad \mathrm{BaCe}_{0.9} \mathrm{Y}_{0.1} \mathrm{O}_{3}$-based electrolytes exhibited rather mixed electronic conductivity. This caused an increase in values of polarisation resistance, especially in the cathode reduction process. On the other hand, in the case of a hydrogen-rich gas atmosphere, the BCY-based electrolytes exhibited practically pure proton conductivity. These results clearly indicated that cathode polarisation has a considerable impact on the performance of a SOFC with a BCY electrolyte.

\section{Conclusions}

$\mathrm{Ba}_{0.9} \mathrm{Ca}_{0.1} \mathrm{Ce}_{0.9} \mathrm{Y}_{0.1} \mathrm{O}_{3}$-d (10CBCY) protonconducting disc-shaped ceramic electrolytes were obtained. Based upon confocal and scanning microscopy observation, no cracks or other surface defects were found for sintered samples of 10CBCY; only low closedporosity content was observed in the case of $10 \mathrm{CBCY}$ sintered samples. The obtained 10CBCY protonconducting ceramic was applied as an electrolyte for IT-SOFC operating within a temperature range of $550-750^{\circ} \mathrm{C}$. An increase was observed in the performance of $\mathrm{H}_{2}, \mathrm{Pt}|10 \mathrm{CBCY}| \mathrm{Pt}, \mathrm{O}_{2}$ in this range. The results of these initial electrochemical tests appear to justify further investigations of an SOFC utilising 10CBCYwith reduced thickness.

\section{Acknowledgements}

I would like to thank Dr Magdalena Dudek for useful discussions and advices during experiments and manuscript preparation. This work was supported by the contract no. 15.11.201.345.

\section{References}

1. Fuel Cell Handbook (Seventh edition) by EG\&G Technical Services, Inc Morgantown (2004)

2. W. Lewandowski Proekologiczne odnawialne źródła energii, Red; Warszawa WNT 2013, ISBN 978-837926-041-6

3. N.H. Behling Fuel cells: Current Technology Challenges and Future Research Needs, Elsewier Science Technology (2013)

4. A.B. Stambouli, E. Traversa Renew. Sust. Energ. Rev. 6 433-455 (2002)

5. Z. Gao, L.V. Mogni, E.C. Miller, J.G. Railsback, S.A. Barnett, Energy Environ. Sci. 9 1602-1644 (2016)

6. O.Z. Sharaf, M. F. Orhan, Renew. Sust. Energ. Rev. 32 810-853 (2014)

7. P. E. Dodds, I. Staffell, A.D. Hawkes, F. Li, P. Grunewald, W. McDowall, P. Ekins, Int. J. Hydrogen Energy 40 2065-2083 (2015)

8. P. Tomczyk, J. Power Sources 160 858-862. (2006)

9. R.O.Stroman, M.W. Schuette, K. Swider-Lyons, J.A. Rodgers, D.J. Edwards, Int. J. Hydrogen Energy 39 11279-11290 (2014)

10. A. Alaswad, A. Baroutaji, H. Achour, J. Carton A. Makky, A.G. Olabi, Int. J Hydrogen Energy (to be published) (2016)

11. D.J.L. Brett, A. Atkinson, N.P. Brandon, S.J. Skinner, Chem. Soc. Rev. 37 1568-1578 (2008)

12. H. Matsumoto, I. Nomura, S. Okada, T. Ishihara, Solid State Ionics 179 1486-1489 (2008)

13. A. Buonomano, F. Calise, M.D. Accadia, A. Palombo, M. Vicidomini, App. Ener. 156 32-85 (2005)

14. S. Mekhilef, R. Saidur, A. Safari Renew. Sust. Energ. Rev. 16 981-989 (2012)

15. Y. Xiong, K. Yamaji, T. Horita, N. Sakai, H. Yokokawa J. Electroch. Soc. 151 A407-A412 (2004)

16. J.G. Lee, J.H. Park, Y.G Shul, Nat. Commun. 54045 (2004)

17. M. Dudek, Journal of the European ceramic society 28 965-971 (2008) 
18. D.A. Medvedev, J.G. Lyagaeva, E.V. Gorbova, A.K. Demin, P.Tsakaras, Prog. Mater. Sci. 75 38-79 (2016)

19. E. Fabbri, D. Pergolesi, E. Traversa, Chem. Soc. Rev. 39 4355-4369 (2010)

20. B. Timurkutluk, C. Timurkutluk, M. D. Mat, Y. Kaplan Renew. Sust. Energ. Rev 56 1101-1121 (2016)

21. M. Dudek, B. Lis. A. Rapacz-Kmita, M. Gajek, A. Raźniak, E. Drożdż, Mater. Sci-Poland vol. 341 (2016)

22. https://fuelcellmaterials.com/

23. http://www.kerafol.com/en/sofc/ 